\title{
Industry Payments to Academic Physicians: a Comparison of Reporting to Two Government Agencies
}

\author{
Timothy S. Anderson, MD, MA ', Chester B. Good, MD, MPH $H^{2,3,4,5}$, and Walid F. Gellad, MD, MPH 4,5,6 \\ 'Division of General Internal Medicine, University of California San Francisco, San Francisco, CA, USA; ${ }^{2}$ Center for High Value Pharmacy Initiatives, \\ University of Pittsburgh Medical Center Health Plan, Pittsburgh, PA, USA; ${ }^{3}$ University of Pittsburgh School of Medicine and Pharmacy, Pittsburgh, PA, \\ USA; ${ }^{4}$ VA Center for Health Equity Research and Promotion, Pittsburgh, PA, USA; ${ }^{5}$ Division of General Internal Medicine, University of Pittsburgh, \\ Pittsburgh, PA, USA; ${ }^{6}$ Center for Pharmaceutical Policy and Prescribing, University of Pittsburgh, Pittsburgh, PA, USA.
}

J Gen Intern Med 33(10): 1604-6

DOI: $10.1007 / \mathrm{s} 11606-018-4527-2$

(C) Society of General Internal Medicine 2018

$\mathrm{T}$ he Physician Payments Sunshine Act requires public reporting of payments to physicians by healthcare companies. In 2014, the Centers for Medicare \& Medicaid Services (CMS) Open Payments database documented over $\$ 3$ billion in non-research payments from healthcare companies to physicians. ${ }^{2}$ However, Open Payments relies on company reporting, and its breadth is limited to companies which manufacture federally covered drugs, devices, or medical supplies. While Open Payments marked the first mandatory public reporting of payments specific to physicians, the Securities Exchange Commission (SEC) requires companies to disclose compensation paid to directors. Prior research has shown that academic physicians frequently receive significant compensation and stock for serving on company boards of directors. ${ }^{4}$ Thus, physician-director relationships create a unique opportunity to compare two sets of disclosures - those to CMS and those to the SEC.

\section{METHODS}

We conducted a cross-sectional analysis of payments made by US healthcare companies to academic physicians who served on boards of directors in 2014, comparing payments disclosed through definitive proxy statements submitted to the SEC with payments disclosed to Open Payments. Open Payments requires companies to report all direct and indirect payments (cash, stock, options, and in-kind services) for all activities not made in connection with a research agreement, which may include directorships. ${ }^{2}$ The SEC requires reporting of all compensation paid for directorship, including cash, stock, and option payments. ${ }^{3}$ We examined the boards of directors of companies listed on the New York Stock Exchange or NASDAQ and included all academic physician-directors who served the entirety of

Published online June 12, 2018
2014. We used a previously published approach to identify academic directors in SEC disclosures. ${ }^{4}$ We focused on academic physicians given their unique duties in education, clinical care, and research. ${ }^{5}$ For each director identified in SEC disclosures, we searched Open Payments by full name and state for all non-research compensation and stock ownership from the company they directed. ${ }^{2}$ We compared the frequency and magnitude of disclosures in the SEC and Open Payments databases in 2014.

\section{RESULTS}

In company disclosures to the SEC, we identified 145 academic physicians-directors, of whom 89 (61\%) served on companies which were not listed in the Open Payments database. Of the remaining 56 physiciandirectors from companies reporting to both Open Payments and the SEC, $36(64 \%)$ had at least one payment disclosed in the Open Payments database from the company on whose board they served, $11(20 \%)$ had only payments from other companies, and $10(18 \%)$ had no payments disclosed. Only 12 physician-directors $(21 \%)$ had ownership interests disclosed in Open Payments (Table 1).

Of the 32 physician-directors with compensation disclosed in both databases, the median compensation disclosed to the SEC for board membership was greater than all compensation disclosed in Open Payments, which may include compensation beyond board membership (\$236,077 vs $\$ 139,950)$. Magnitude of compensation disclosed varied between sources, with greater compensation more often disclosed to SEC than Open Payments (Fig. 1). We were unable to compare magnitude of ownership interests, which are reported as shares in SEC and estimated values in Open Payments.

\section{DISCUSSION}

The Open Payments program has yielded important insights into financial relationships between physicians 
Table 1 Company-reported disclosures of payments to academic physician-directors in the SEC and Open Payments, 2014

\begin{tabular}{|c|c|c|}
\hline & $\begin{array}{l}\text { Reported to } \\
\text { SEC }\end{array}$ & $\begin{array}{l}\text { Reported to } \\
\text { Open Payments }\end{array}$ \\
\hline $\begin{array}{l}\text { Physician-directors with any } \\
\text { disclosed financial relationship, } \\
\text { no. (\%)* }\end{array}$ & $56(100 \%)$ & $36(64 \%)$ \\
\hline $\begin{array}{l}\text { Physician-directors with any } \\
\text { compensation disclosed, no. } \\
(\%)^{\dagger}\end{array}$ & $52(93 \%)$ & $35(63 \%)$ \\
\hline $\begin{array}{l}\text { Physician-directors with any } \\
\text { ownership interest disclosed, } \\
\text { no. }(\%)^{\ddagger}\end{array}$ & $56(100 \%)$ & $12(21 \%)$ \\
\hline $\begin{array}{l}32 \text { physician-directors with } \\
\text { compensation reported in both } \\
\text { databases, median (IQR) \$ }\end{array}$ & $\begin{array}{l}236,077 \\
(163,711- \\
298,058)\end{array}$ & $\begin{array}{l}139,950 \\
(76,656- \\
249,554)\end{array}$ \\
\hline $\begin{array}{l}24 \text { physician-directors with } \\
\text { compensation reported in SEC } \\
\text { database only, median (IQR) \$ }\end{array}$ & $\begin{array}{l}271,012 \\
(213,255- \\
311,652)\end{array}$ & $0(0-0)$ \\
\hline $\begin{array}{l}\text { Sum of disclosed compensation } \\
\text { to all physician-directors, } \$\end{array}$ & $17,476,520$ & $9,633,481$ \\
\hline
\end{tabular}

$S E C$, Securities and Exchange Commission; IQR, interquartile range * Financial relationship may include compensation (defined by SEC disclosures as any fees earned or paid in cash, stock awards, option awards or other payment and defined by Open Payments as payments or other transfers of value not made in connection with a research agreement) and/or ownership and investment interests held in the company

+Compensation include all payments to the physician-director from the company whose board they direct. SEC reporting includes solely compensation for board membership while CMS Open Payments reporting may include both compensation for board membership and additional payments from the company for other services rendered by the board member. Of the 35 physician-directors with compensation listed in Open Payments, three were listed as receiving no compensation SEC disclosures

tOwnership interests include stocks and options of the company which the physician-director is a board member. Ownership interests were reported as shares in SEC and estimated values in Open Payments and thus the magnitude could not be compared

and industry. ${ }^{6}$ However, our findings highlight two major limitations of Open Payments which researchers and policymakers should recognize. First, three-fifths of physician-director relationships we identified involved healthcare companies not listed in Open Payments. Many companies are exempt from Open Payments reporting including companies with only products in development or clinical trials, companies which manufacture only non-prescription products (such as supplements), and many healthcare services, health insurance, and medical equipment companies. However, financial relationships between exempt companies and physicians may be significant and deserve the same level of scrutiny as companies with marketed products, thus CMS should consider required reporting for all healthcare companies.

Second, we found large discrepancies in the magnitude of payments disclosed to the SEC and to Open Payments, which point to the challenge of unverified reporting but also to a lack of clarity of CMS reporting expectations for board members. CMS should consider revising requirements to mandate specific reporting of physician-director relationships, given the financial mag-

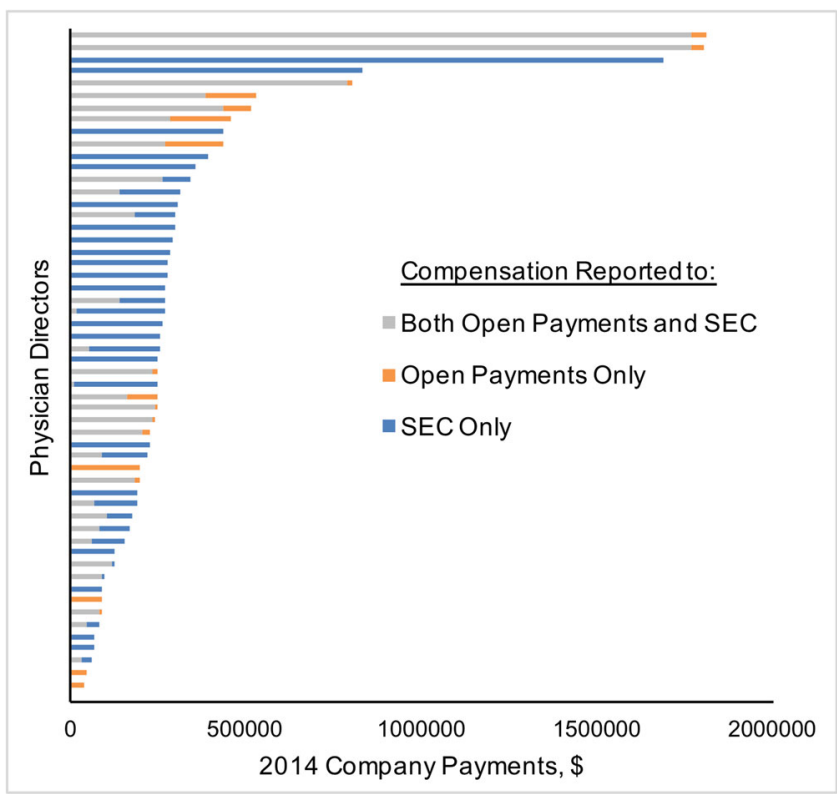

Figure 1 Company-reported compensation to physician-directors to the SEC and Open Payments databases, 2014. Note: SEC, Securities and Exchange Commission. Each bar represents total compensation to a single physician-director from the company whose board they direct. Compensation is divided by magnitude of compensation reported to the SEC, which reflects solely compensation for board membership, and reported to the CMS Open Payments database,

which may include compensation for board membership and additional payments from the company for other services rendered by the board member. Bars in blue represent payments in the SEC database that were not reported in Open Payments. Figure includes the 56 directors at companies reporting to the Open Payments database and excludes the additional 89 directors on healthcare companies reporting to the SEC but which did not report any payments to the Open Payments database. One director was listed as receiving no compensation in either database.

nitude and unique conflicts of interest these relationships pose. ${ }^{5}$ To meet the Physician Payments Sunshine Act's goal of developing a greater understanding of financial relationships in healthcare, continued improvement in reporting mechanisms is crucial.

Corresponding Author: Timothy S. Anderson, MD, MA; Division of General Internal MedicineUniversity of California San Francisco, 1545 Divisadero Street, 2nd Floor, San Francisco, CA 94115, USA (e-mail: timothy.anderson@ucsf.edu).

Author Contribution Study concept and design: All authors Acquisition of data: Anderson

Analysis and interpretation of data: All authors

Drafting of the manuscript: Anderson

Critical revision of the manuscript for important intellectual content: All authors

Statistical analysis: Anderson

Administrative, technical, and material support: Anderson, Good, and Gellad

Study supervision: Good and Gellad

Funding/Support Dr. Anderson was supported by a National Research Service Award training grant (NRSA T32HP19025-14-OO), University of California San Francisco. All other authors report receiving no external funding for this work. 


\section{Compliance with Ethical Standards:}

Role of the Sponsor: The funder supported research time for Dr. Anderson and did not fund the study directly; thus, the funder had no role in the design and conduct of the study; collection, management, analysis, and interpretation of the data; or preparation, review, or approval of the manuscript.

Disclaimer: Dr. Anderson had full access to all of the data in the study and takes responsibility for the integrity of the data and the accuracy of the data analysis. The contents represent the views of the authors only and not necessarily those of the Department of Veterans Affairs or the US government.

Conflict of Interest: The authors declare that they do not have a conflict of interest.

\section{REFERENCES}

1. Centers for Medicare and Medicaid Services. Medicare, Medicaid, Children's Health Insurance Programs: transparency reports and reporting of physician ownership or in- vestment interests. Fed Regist 2013;78:9457-528.
2. Open Payments. Baltimore, MD: Centers for Medicare \& Medicaid Services; 2015. https://openpaymentsdata.cms.gov/summary. Accessed May $11^{\text {th }}$, 2018.

3. US Securities and Exchange Commission. Electronic data gathering, analysis, and retrieval system. http://www.sec.gov/edgar.shtml. Accessed May $11^{\text {th }}, 2018$.

4. Anderson TS, Good CB, Gellad WF. Prevalence and compensation of academic leaders, professors, and trustees on publicly traded US healthcare company boards of directors: cross sectional study. BMJ. 2015;351:h4826.

5. Lo B. Serving two masters-conflicts of interest in academic medicine. $N$ Engl J Med. 2010;362:669-71.

6. Cherla DV, Olavarria OA, Holihan $\mathbf{J L}$, et al. Discordance of conflict of interest self-disclosure and the Centers of Medicare and Medicaid Services. J Surg Res. 2017;218:18-22. 